of establishing a diagnosis of aortic arch vessel injury when bleeding, expanding hematoma, absent pulses, and shock are not obvious. Arteriography is not entirely reliable, the false negative rate being approximately $10 \%{ }^{4}$ In our case, the only sign leading to suspicion of an aortic arch tear was the small mediastinal extravasation of the contrast material, the outline of the aortic arch and great vessels being preserved in the other areas.

Patients with aortic or great vessel tears must be treated on an urgent basis because their condition can deteriorate at any time. The literature seems to be about equally divided between those who believe strongly that the repair of cerebral vessels in the presence of a neurologic deficit is associated with a higher risk of mortality and those who do not. Our case, however, confirmed that an obvious neurologic deficit was not worsened by carotid reconstruction and neurologic recovery may even be possible. ${ }^{5} \mathrm{We}$ believe that cannulation of carotid arteries provides a margin of safety in patients who have acute neurologic deficit attributable to cerebral ischemia after trauma. In conclusion, severe neurologic injury after blunt trauma may be due to the aortic arch tears near the origins of the innominate artery and the LCCA. Aortography should be used more liberally in patients in whom the neurologic deficit could overshadow the vascular trauma and then delay diagnosis. With the slightest suspicion, mediastinal exploration is recommended because it will allow recognition and surgical management of occult injuries. Carotid revascularization should be attempted because the neurologic impairment may be progressively reversible.

We gratefully acknowledge the technical assistance of Michel Beux.

\section{REFERENCES}

1. Rosenberg JM, Bredenberg CE, Marvasti MA, Bucknam C, Conti C, Parker FB. Blunt injuries to the aortic arch vessels. Ann Thorac Surg 1989;48:508-13.

2. Bachet J, Guilmet D, Goudot B, et al. Cold cerebroplegia: a new technique of cerebral protection during operations on the transverse aortic arch. J Thorac Cardiovasc Surg 1991;102:8594.

3. Vasko JS, Raess DH, Williams TE Jr, et al. Nonpenetrating trauma to the thoracic aorta. Surgery 1977;82:400-6.

4. Johnston RH Jr, Matthew JW Jr, Mattox KL. Innominate artery trauma: a thirty year experience. J Vasc Surg 1993;17: 134-40.

5. Robbs JV, Baker LW, Human RR, Vawda IS, Duncan H, Rajaruthnam P. Cervicomediastinal arterial injuries. Arch Surg 1981;116:663-8.

\title{
AORTIC VALVE REPLACEMENT IN RELAPSING POLYCHONDRITIS
}

\author{
Loïc Lang-Lazdunski, MD, Yves Pansard, MD, and Ulrik Hvass, MD, Paris, France
}

Relapsing polychondritis is a rare inflammatory multiorgan disorder affecting cartillaginous structures and other connective tissues. More than 600 cases have been reported to date in the literature. Serious cardiovascular complications appear in about $25 \%$ of patients with relapsing polychondritis, the most frequent being aortic or mitral regurgitation $(11.1 \%)$ and aortic aneurysms $(6.1 \%)$. We report the first Bentall-type operation in a patient with relapsing polychondritis and review the literature to point out the factors that influenced morbidity and mortality of patients requiring aortic valve replacement to

From the Department of Thoracic and Cardiovascular Surgery, Hopital Bichat, Paris, France.

Received for publication Oct. 21, 1996; accepted for publication Nov. 4, 1996.

Address for reprints: Loïc Lang-Lazdunski, MD, Service de Chirurgie Thoracique et Cardiovasculaire, Hopital Bichat, 46 rue Henri Huchard, 75877 Paris cedex 18, France.

J Thorac Cardiovasc Surg 1997;114:131-2

Copyright (C) 1997 by Mosby-Year Book, Inc.

$0022-5223 / 97 \$ 5.00+0 \quad \mathbf{1 2 / 5 4 / 7 9 1 8 0}$ determine the ideal surgical procedure for patients with relapsing polychondritis.

Case report. A 39-year-old man with relapsing polychondritis (RP) for 4 years and requiring permanent corticoid and immunosuppressive therapy for severe bilateral scleritis was admitted to our institution for recent shortness of breath. Severe aortic regurgitation associated with moderate aneurysmal dilatation of the ascending aorta (46 $\mathrm{mm}$ in diameter) were diagnosed, and the patient was referred to our department for surgical correction.

He underwent operation on February 24, 1995. The surgical procedure consisted of a Bentall-type operation with a No. 25 mechanical valvular prosthesis, with the coronary arteries being reimplanted with the use of the button technique. The postoperative course was uneventful, and the patient was discharged home on day 30 . Histologic examination of the aortic root showed acute panaortitis lesions: the intima was thickened, and the media showed extensive loss and fragmentation of elastic fibers. There were also perivascular mononuclear cell infiltrates in the outer media and in the adventitia. The aortic valve was thickened and contained inflammatory mononuclear cell infiltrates. 
Eighteen months after the operation, the patient was without symptoms with a regimen of prednisone $25 \mathrm{mg} /$ day and a permanent immnunosuppressive therapy. Doppler echocardiography showed a well-functioning aortic prosthesis, no paraprosthetic leak, no false aneurysm, and a remaining thoracic aorta of normal caliber.

Discussion. Although the first aortic valve replacement in a patient with RP was reported in 1967, the ideal surgical procedure for such patients still remains to be determined. An extensive review of the literature reported by us in 1995 disclosed only 21 cases of aortic valve replacement, associated with mitral valve replacement in six and supracoronary graft replacement of the ascending aorta in three. ${ }^{1}$ All patients had aortic insufficiency related to aortic root enlargement $(77.7 \%)$ or exclusive valve involvement $(22.3 \%)$ or both mechanisms. All patients with aortic root involvement exhibited macroscopic or microscopic signs of aortitis. Six patients had an aneurysm of the ascending aorta within a mean 2.2-year postoperative delay. Three patients underwent reoperation for aortic prosthesis dehiscence with an operative mortality of $66.6 \%$; the three others died. In these patients, there is no doubt that corticosteroid therapy contributed to aortic tissue fragilization that resulted in suture leakage and prosthesis dehiscence. Also, two additional patients probably died of a ruptured ascending aorta within a 2-year postoperative delay (sudden death, no autopsy obtained). ${ }^{1}$ Consequently, we recommend a prophylactic Bentall-type operation in all patients with RP requiring aortic valve replacement. This procedure carries a minimal risk of morbidity/mortality and has proven to be safe and efficient in other diseases with aortic involvement, such as Marfan syndrome. ${ }^{2-5}$ Furthermore, we believe that the coronary button reimplantation technique associated with the exclusion technique for the aortic anastomoses is the most reliable method for prevention of bleeding and late false aneurysm formation at suture lines because all diseased aortic tissue is eliminated. 5 This option may prevent precoce or late anastomosis dehiscence and thus avoid further high-risk reoperations in fragile immunosuppressed patients.

\section{REFERENCES}

1. Lang-Lazdunski L, Hvass U, Paillole C, Pansard Y, Langlois J. Cardiac valve replacement in relapsing polychondritis. A review. J Heart Valve Dis 1995;4:227-35.

2. Gott VL, Pyeritz RE, Cameron DE, Greene PS, McKusik VA. Composite graft repair of Marfan aneurysym of the ascending aorta. Results in 100 patients. Ann Thorac Surg 1991;52:38-45.

3. Cohn L, Rizzo RJ, Adams DH, et al. Reduced mortality and morbidity for ascending aortic aneurysm resection regardless of cause. Ann Thorac Surg 1996;62:463-8.

4. Lewis CTP, Cooley DA, Murphy MC, Talledo O, Vega D. Surgical repair of aortic root aneurysms in 280 patients. Ann Thorac Surg 1992;53:38-46.

5. Kouchoukos NT, Wareing TH, Murphy SF, Perrillo JB. Sixteen-year experience with aortic root replacement. Results in 172 operations. Ann Surg 1991;214:308-20.

\title{
PERICARDIAL PATCH AUGMENTATION OF RESTRICTIVE INNOMINATE VEIN AND DIVISION OF LEFT SUPERIOR VENA CAVA IN UNROOFED CORONARY SINUS SYNDROME
}

\author{
Jacques A. M. van Son, MD, Volkmar Falk, MD, and Friedrich W. Mohr, MD, Leipzig, Germany
}

The unroofed coronary sinus syndrome is a spectrum of cardiac anomalies in which part or all of the common wall between the coronary sinus and the left atrium is absent; in most cases the anomaly is associated with a persistent left superior vena cava (SVC). ${ }^{1}$ In the absence of the coronary sinus, the left SVC connects with the left upper corner of the left atrium, between the opening of the left

From Herzzentrum, University of Leipzig, Leipzig, Germany.

Received for publication Oct. 21, 1996; accepted for publication Nov. 12, 1996.

Address for reprints: Jacques A. M. van Son, MD, Department of Cardiac Surgery, Herzzentrum Leipzig, Russenstrasse 19, Leipzig D-04289, Germany.

J Thorac Cardiovasc Surg 1997;114:132-4

Copyright (C) 1997 by Mosby-Year Book, Inc.

$0022-5223 / 97 \$ 5.00+0 \quad \mathbf{1 2 / 5 4 / 7 9 1 8 7}$ atrial appendage and the orifice of the left superior pulmonary vein. ${ }^{2}$ A coronary sinus atrial septal defect (ASD) is present in the posteroinferior region of the atrial septum, in the usual position of the coronary sinus orifice. The innominate vein is absent in $80 \%$ to $90 \%$ of patients with the unroofed coronary sinus syndrome and left SVC. ${ }^{3,4}$

The diagnosis of isolated unroofed coronary sinus syndrome with persistent left SVC usually is an indication for operation to avoid long-term arterial desaturation and its detrimental sequelae. In the absence of an innominate vein, the preferred repair consists of excision of the entire atrial septum except the anterior limbus, which is preserved as a protection for the atrioventricular node and bundle, ${ }^{5}$ followed by placement of a pericardial patch in such a fashion that all of the pulmonary veins drain under the patch to the mitral valve orifice. A second useful method of repair consists of rerouting the coronary sinus 